\title{
Technology as Actors in Service Systems
}

\author{
Md Abul Kalam Siddike \\ Tokyo Institute of Technology \\ kalam.siddike@gmail.com
}

\author{
Kazuyoshi Hidaka \\ Tokyo Institute of Technology \\ hidaka.k.ac.@m.titech.ac.jp
}

\author{
Youji Kohda \\ Japan Advanced Institute of Science \\ and Technology \\ kohda@jaist.ac.jp
}

\begin{abstract}
Service systems are defined as dynamic configurations of resources (people, organizations, technology and shared information), interconnected internally and externally by value propositions with other service systems. Resources are constantly evolving, as are the capabilities and roles of resources in service systems. Cognitive technologies incorporate rapidly advancing artificial intelligence (AI) capabilities. Therefore, their roles are on a trajectory of increasing agency and self-directed interactions with other resources and service systems. With this in mind, a framework for service systems in which AI-based cognitive assistants (CAs) become responsible actors is the current research challenge. Because AI-based CAs have already started to play different roles in service systems. One contribution of this research is to clarify that service system entities are responsible actors, and address the question: Under what conditions does a technology such as a Cognitive Assistant (CA) become a responsible actor?
\end{abstract}

\section{Research Background}

Artificial intelligence (AI) progress is gradually changing the role of technology in service systems. The progress of AI can be categorized in terms of the four roles of technology namely assistive (human-inthe-loop, hard-wired-system), augmenting (humanin-the-loop, adaptive-system), automating (nohuman-in-the-loop, hard-wired-system), and autonomic (no-human-in-the-loop, adaptive system) [34]. The assistive type of AI technology fits well within the traditional service science view of using technology as tool for improving performance [23]. But the remaining three categories, namely augmenting, automating and autonomic AI technologies, imply increasing degrees of agency and direct interactions with people and environment. The changing role of technology, from a tool towards "actor" in value creation calls for new conceptualization toward technology in service science [20]. The rapid advances in AI wrote by Maglio [20]: "what of real autonomous technologies, ones that go beyond what author or creator specially wrote-or ones appear to have their own ability to deliberate, their own agency?............". These questions clearly urge service science researchers to define more clearly the notion of "agency of technology" in service systems. Therefore, the main purpose of this paper is to clarify that service system entities are responsible actors, and address the question: under what conditions does a technology such as a cognitive assistant (CA) become a responsible actor in service system?

The rest of the paper is organized in the following ways: section 2 reviews the literature on the roles of technologies in service systems and the agency of AIbased cognitive assistants (CAs); Section 3 discusses the research methodology; section 4 shows the results of data analysis; section 5 describes the emergence of AIbased CAs as actors in service systems; and finally, the paper concludes with summarization and future research directions.

\section{Literature Review}

\subsection{Roles of Technologies in Service Systems}

2.1.1. Service systems. Service system is one of the fundamental abstractions of service science, along with the concepts of value and value co-creation [21] [48-49]. A service system is a dynamic configuration of people, technologies, organizations and shared information interconnect by value propositions to other service system entities, that interact over time for co-creation of value [53-54]. Service system entities interact via value proposition to co-create value for both interacting entities [22] [48] [52]. The function of a service system is to make use of its own resources and the resources of others to improve its circumstances and that of others. On the contrary, service ecosystem is one of the core 
concepts of service-dominant (S-D) logic. A service ecosystem is defined as "a relatively self-contained, self-adjusting system of resource integrating actors that are connected by shared institutional logics and mutual value creation through service exchange" [18].

2.1.2. Role of technologies in service systems. Both service science and S-D logic have emphasized the role technologies play in service systems and service ecosystems [1] [48] [56]. Service science considers technology as one of the four types of resources. In a service system, technology is the resource that has no rights and responsibilities [48-49]. In this view, technology contributes to co-creation of value by enabling the sharing of information within and across service systems [48]. In the structurational model of technology, Orlikowski [27] viewed technology as a medium and an outcome of human action. Similarly, Arthur [2] considered technology as a process as well as a product of human action. Adopting the view from Orlikowski [27], S-D logic considers technology as the most efficient tool for enhancing resources exchange and value co-creation [1] [56]. S-D logic conceptualizes technology as an operant resource [1] [56]. As technology influences and is influenced by human actions and institutions in service ecosystems [1]. In addition, technology could play five key roles in customer and actor engagement which include focal engagement object, engagement platform, initiator of engagement, shaper of engagement institutional context, and focal engaging actor [16]. Service systems are getting larger and larger and evolving from traditional service systems to smart service systems to wise service systems [42] [51]. In the age of smart technologies, service system requires systematic exploration of resource configuration to improve existing offerings, create new offerings, or reconfigure ecosystem partners [19].

2.1.3. Role of CAs in service systems. AI based CAs are new decision tools [38-40] [47]. They are capable of providing high quality recommendations [43-44] [46] [51]. They help people making better data driven decision understanding the environment around them [50].

In service systems, CAs are new decision tools, able to provide people with high-quality recommendations and help people make better data driven decision understanding the environment of people [47] [50-51]. On the other hand, S-D logic considers technology as operant resources enhancing human viability, especially through the creation of new resources [1] [56-59]. But, recently Siddike and Kohda [38] considered CAs as operant resources in the service system, as CAs interact with human actors to provide high quality information that help to create new resources for human actors. At the same time, through the interaction, CAs could learn from human actors and improve its capabilities. In the sense of service science and S-D logic, both actors (CAs and human) are benefited through the harmonious interactions among them.

\subsubsection{Relative advantages and trustworthiness as} important factors that influence users' interaction with CAs. Currently, the capabilities of CAs are limited and very new to the market. Therefore, in this initial level, trustworthiness of users toward using CAs and relative advantages of using $\mathrm{CAs}$ - are considered as the most influential factors for influencing people to use CAs [28] [39-41]. In general, people have the attitude or willingness to believe their partners [33]. In the case of economics, actors (people, organizations, or agencies) have the willingness to believe in the information or actions provided by other actors [29]. In the case of organizations, team members have the tendency to trust in other team members [24]. In a similar way, people have the willingness to trust in automation [15]. In the same way, people will have the tendency to trust in their CAs [39-41]. When CAs are reliable and attractive, people have more of an intention to use them for different purposes [8]. In addition, when CAs produce more emotional feelings in users, users will have more of an intention to accept them. As a result, users' trustworthiness toward CAs positively influences their intention to interact with CAs [39-41].

The term 'relative advantages' adopted from theory of 'diffusion of innovation' by Rogers [35]. Innovativeness provides relative advantages to users of a particular technology [35]. Technology acceptance model (TAM) and technology readiness index (TRI) described the users' acceptance and use of technology based on the relative advantages of technology [8] [32]. Especially, Davis [8] described that using any system would enhance his or her job performance and using a particular system would be free of effort. Similarly, Parasuraman [32] referred to people's propensity to embrace and use new technologies for accomplishing goals in home life and at work. Siddike and Kohda [3941] considered CAs as innovation. Using CAs, users receive advantages. Even if users use the same CAs, but the advantages differ from users to users. As a result, relative advantages play the most important role for users to interact with CAs.

\subsection{Agency of CAs: A Service System View}

2.2.1. Agency. There are several dictionary meanings of the word "agency". Agency is defined as the action or intervention of producing a particular effect [30]. In addition, agency is also defined as the capacity, 
condition or state of acting [25]. Furthermore, agency is deified as the capacity to act based on the action of an agent [37]. Finally, agency is defined as the capacity or property of actors to make things happen. That means agency is the capacities of actors to produce effects [6]. In this research, agency is defined as the capability or capacity or ability of actors (either human actors or technological actor) to act purposefully in a given environment or context.

2.2.2. Agency in different disciplines. Different disciplines consider agency differently. In philosophy and sociology, agency is used to indicate the ability of individuals to act or behave in the environment or cultural context that help to emerge structure of the society [5] [12]. Social structures are viewed as the outcomes of individual actions [12]. The individual's abilities are influenced by structure, structures are influenced through the exercise of agency [12]. In economics, agency is considered as the contracts between two parties that shape the behavior among them. Agency in the form of contracts works as governance mechanism to shape the actions of parties involved in transactions [29] [36] [62-63]. In psychology, human agency evolves as self-organizing, self-regulating and self-reflecting nature. Human agency can be exercised through direct personal agency; through proxy agency relying on the efforts of intermediaries; and by collective agency operating through shared beliefs of efficacy, pooled understandings, groups aspirations and incentives systems, and collective actions [3]. Finally, in computer science, agency is considered as the abilities of a software agent to act for users or other programs [26].

2.2.3. Actors in service systems. In general, actor is a participant in an action or a process. In service science, Spohrer and Maglio [48-49] defined service system entities are the fundamental abstraction of service science including formal and informal service system entities. A formal service system entity is a legal, economic entity with rights and responsibilities codified in written laws. An informal service system entity uses promises, morals, and reciprocity in place of contracts, written laws and money [52]. Similarly, Lusch and Vargo [18] indicated actors are entities that have agency, the ability to act purposefully. In S-D logic, actors are defined as the parties involved in resource integration, service exchange and value co-creation [59]. S-D logic highlights that all social and economic actors (e.g. individuals, businesses, households, etc.) are resource integrators [58-59]. In service ecosystem, actors operate on and integrate various available resources, guided by institutions and institutional arrangements (rules and regulations), in order to co-create value [59-60]. In S-D logic, multiple actors are involved in value co-creation through resource integration and service-for-service exchange. Here, multiple actors include service providers, firms, customers and other social community as beneficiary, business organizations, government organizations, public and private organizations as well as society as a whole considered as actors [18].

2.2.4. Functions of actors in service systems. The main function of actors in S-D logic is to integrate resources for the benefit of other actors [59]. Actors have two basic resources: physical and mental skills. These resources are "operant" because actors use them to create beneficial effects by acting on other resources (operand). Actors develop and apply these resources and exchange their application with other actors to enhance the viability of the service ecosystem [18]. Actors integrate resources from market, private and public sources to create new resources. And the created new resources again integrate with other resources. These processes are called nature and evolution of resource integration in S-D logic [18]. The integration and evolution of resources are coordinated by institutions and institutional arrangements [59]. As institutions and institutional arrangements shape the behavior of the actors in the service ecosystem [60].

2.2.5. Agency in service systems. The rights and responsibilities of actors in service systems are considered as agency in service science [48] [54]. Individuals as human being have the legal rights and responsibilities in service system. In addition, individuals play different roles in service system (i.e. user, citizen, employee, and resident). Secondly, organizations as group of individuals have also the legal rights in the service system. Organization has different roles toward service system (i.e. provider, user, company, government, employer, and owner). Technology and shared information are considered as physical resource in service system. But technology and shared information have no legal rights and responsibilities in service system [48]. On the contrary, technology is considered as operant resource in service ecosystem [2]. Technology as operant resource means technology has the primary knowledge and skills for enhancing human viability, especially through the creation of new resources [2] [59].

2.2.6. Technological agency in service systems. AI technologies have already started gaining rights and responsibilities, though it is a subject of significant legal and philosophical debatable [14] [61]. More recently, we see the technology-driven change in rights, responsibilities and governance of actors have already happening with the General Data Protection Regulation 
(GDPR) of the European Union [10]. GDPR begins to specify and standardize, in a wide range of context, the rights and the responsibilities of (1) data controller (an organization that collects data from EU residents), (2) data processor (an organization that process data on behalf of a data controller like cloud service providers), and (3) the data subject (a person based in the EU). GDPR provides an operational definition of rights and responsibilities, and penalties for failing to meet responsibilities. Citizens, data subjects, data processors, and data controllers are currently all service system actors with well-defined rights and responsibilities [31]. The actor network theory (ANT) of Latour [17] could explained the non-human actors and agency in service systems.

In addition, Siddike and Kohda [38] conceptualized "autonomous agency" as the agency of CAs in the service system. Autonomous agency defined as the capabilities of CAs doing things by themselves having their own rights and responsibilities. As Bostrom [4] stated that CAs (intelligent systems) consist of intelligent parts that are themselves capable of doing things. And for some purposes, autonomous agents have their own rights.

As of today, CAs are capable of providing precise recommendations by understanding the emotions, feelings, context and environments of people they interact. Therefore, they are learning from those interactions and are improving their existing models. At the same time, CAs are capable of learning from billions of structured and unstructured data over the internet. As a result, CAs are evolving and gaining more rights and responsibilities (citizenship or GDPR). Over the period of time, "autonomous agency" will emerge as institution in service systems.

\section{Research Methodology}

A qualitative research method adopts that can be seen as an appropriate approach given the need to develop in-depth understanding of a relatively new area [7] [55] [65-66]. Qualitative studies are well suited to create theoretical constructs, propositions and/or midrange theory [9]. In this research, we geared toward the descriptive approach. As scholars view qualitative research as highly descriptive and stress the social construction of reality [11]. The objective of qualitative research is to describe and possibly explain events and experiences, but never predict [64].

In this research, the 'grounded theory' approach was undertaken to develop the acceptance framework of CAs. Grounded theory is the systematic approach for collecting and analyzing data in order to allow a theory to emerge [13]. Grounded theory includes three basic elements namely: constant comparison between the phenomenon and the contexts, theoretical sampling and theoretical coding [7]. The constant comparison between phenomena and contexts is the core to strengthen the theory. Any rich data with components and conceptual labels, such as events, actions, property, dimensions, codes, concepts, categories and core categories need to be compared. In this research, codes, concepts, categories, and core categories from 32 interviews were constantly compared to emerge the theoretical categories. In grounded theory, theoretical sampling is the process of data collection for generating theory whereby the researcher jointly collects, codes, and analyses their data and decides what data to collect next and where to find them in order to develop theory as it emerges [13].

In this research, initially a total of ten online interviews were conducted with the fellows of first Hawaii International Conference on System Sciences (HICSS) Doctoral Consortium and consecutively the data were coded, constantly compared and generate the emerging categories. While collecting data in the first step, the interviewees were asked to whom should be interviewed next. Because the theoretical sampling in grounded theory used to decide what to observe and whom to interview next [13]. In the second step, a total of 12 (10 face-to-face and 2 online) interviews were conducted with the participants from 5th International Conference on The Human Side of Service Engineering (HSSE), 17-21 July 2017, The Westin Bonaventure Hotel, Los Angeles, California, USA and simultaneously the data were coded and constantly compared for generating the concepts, categories and core categories. Finally, 10 (nine face-to-face and one online) interviews were conducted from IBM Almaden Research Center, San Jose, CA, USA. Then, we constantly compare the codes, concepts, categories and core categories among the three steps to reach the theoretical saturation. The interviews were digitally recorded and transcribed. All the interview data were used throughout the analysis. First of all, all the online and face-to-face interviews data converted into word format. In case of recorded data, we listen it again and again. We verify the contents of the recorded interview several times. It was ensured that any important information was not missing. Then, the word files were then converted into MAXQDA 12. The purpose of conversion was to code the textual data. In this phase, all the data (32 interviews) were converted into MAXQDA software.

\section{Results}

\subsection{Background of the interviewees}

The result shows that 32 interviewees were conducted including 22 general and 10 expert users. 
General users (GU) include students, teachers, researchers and CEO. On the contrary, developers and engineers are considered as expert users (EU). Table 1 shows the types of users.

Table 1. Categorization of interviewees

\begin{tabular}{|l|l|c|}
\hline \multirow{5}{*}{ User types } & $\begin{array}{l}\text { Categorization } \\
\text { of interviewees }\end{array}$ & Number \\
\hline \multirow{5}{*}{ General users } & Student & 15 \\
\cline { 2 - 3 } & $\begin{array}{l}\text { Assistant } \\
\text { professor }\end{array}$ & 3 \\
\cline { 2 - 3 } & Professor & 2 \\
\cline { 2 - 3 } & Researcher & 1 \\
\cline { 2 - 3 } & CEO & 1 \\
\hline \multirow{5}{*}{ Expert users } & Director & 1 \\
\cline { 2 - 3 } & $\begin{array}{l}\text { Executive } \\
\text { director }\end{array}$ & 1 \\
\cline { 2 - 3 } & Anthropologist & $\begin{array}{l}\text { Research staff } \\
\text { member }\end{array}$ \\
\cline { 2 - 3 } & Designer & 2 \\
\cline { 2 - 3 } & $\begin{array}{l}\text { Research group } \\
\text { lead }\end{array}$ & 1 \\
\cline { 2 - 3 } & CEO & 1 \\
\cline { 2 - 3 } & Pseudonym & 32 \\
\hline Total & & 1 \\
\hline
\end{tabular}

The results also show that expert users have longexperienced in designing and developing CAs. Four expert users have more than thirty-year experiences, three have more than twenty-five-year experience, three have more than fifteen-year experience and an expert user has eight-year experience in designing and developing new technologies.

\subsection{Current state-of-art of using CAs}

The results show that most of the users use Apple Siri as followed by Amazon Echo, and Google Home. In addition, a general user uses Google Now and home security device for controlling lights, temperature, air condition and alarming. Furthermore, an expert user uses almost all the current CAs. Table 2 shows the current use of CAs.

It is interesting that not using CAs seem to be the trajectory of CAs that people want to provide a buffer zone. To keep the away from direct contact with reality. The results show that five users ( 3 general and 2 expert) do not prefer to use any CAs. Most of the general users have a perception that using CAs will make them lazy. On the contrary, expert users want to keep direct contact with the nature. Their philosophy is entirely different. They want to be in direct contact with the physical world and other people. They prefer eye-to-eye contact. They do not want to see somebody on the screen. They want to see people eye-to-eye, and face-to-face. They want to feel the emotions in the friendships directly. They prefer just person to nature without the intermediary devices. In addition, they feel that they do not need CAs for keeping track of their exercise for their foods. Because they have a very healthy life style. In this case an expert user indicated that: "I and my wife do not need CAs for keeping track of our exercise for our foods.........In addition, when I go hiking, I do not even take my cell phone with me. But I do take my camera with me. Because I want to have a direct contact with nature (EU2)".

Table 2. Current use of CAs

\begin{tabular}{|l|c|c|c|}
\hline \multirow{2}{*}{ Name of CAs } & $\begin{array}{c}\text { General } \\
\text { users }\end{array}$ & $\begin{array}{c}\text { Expert } \\
\text { users }\end{array}$ & \multirow{2}{*}{ Total } \\
\cline { 1 - 3 } & Yes & Yes & \\
\hline Apple Siri & 15 & 7 & 22 \\
\hline Amazon Echo & 3 & 1 & 4 \\
\hline Google Home & 2 & 1 & 3 \\
\hline IBM Watson & 0 & 1 & 1 \\
\hline Facebook M & 0 & 1 & 1 \\
\hline Samsung Viv & 0 & 1 & 1 \\
\hline Salesforce Einstein & 0 & 1 & 1 \\
\hline Tesla driverless car & 0 & 1 & 1 \\
\hline Google Now & 1 & 1 & 1 \\
\hline $\begin{array}{l}\text { Home security } \\
\text { device }\end{array}$ & 1 & 0 & 1 \\
\hline
\end{tabular}

\subsection{Influential factors for using CAs}

The results show that $41 \%(9 / 22)$ of general users use CAs based on trustworthiness and relative advantages. $36 \%(8 / 22)$ use CAs based on relative advantages. And 23\% (5/22) of general users do not trust their CAs and they do not use their CAs. On the other hand, most of the expert users $(70 \%)$ use CAs only considering its capabilities and functionalities (relative advantages). Only 30\% (3/10) do not consider the relative advantages of CAs. That is why they do not use CAs. Table 3 shows the use of CAs based on trustworthiness and relative advantages. In addition, Table 4 shows the quotes from general and expert users regarding use of CAs based on trustworthiness and relative advantages.

\section{Emergence of AI-based CAs as Actors in Service Systems}

In this section, a theoretical model of emerging service system was developed in which CAs evolve as 
actors. The findings of this research suggest that it is necessary to understand three types of transitions and their relationship to evolve CAs as actors in the near future. These are $\alpha$ (transition in diffusion), $\beta$ (transition in interactions), and $\gamma$ (transition in influencers). Figure 1 shows the theoretical model of service system in which CAs will evolve as actors. Table 5 shows the relations among the transitions.

First of all, the result of this research shows that CAs (AI) are evolving and users' attitudes towards CAs are also changing.

Table 3. Factors influence use of CAs

\begin{tabular}{|c|c|c|c|}
\hline & Trustworthiness + Relative advantages & Relative advantages & Not use any CAs \\
\hline General users & $9 / 22(41 \%)$ & $8 / 22(36 \%)$ & $5 / 22(23 \%)$ \\
\hline Expert users & - & $7 / 10(70 \%)$ & $3 / 10(30 \%)$ \\
\hline
\end{tabular}

Table 4. General and expert users' quotes on trustworthiness and relative advantages

\begin{tabular}{|c|c|c|}
\hline Users & Factors & Interviewees' quote \\
\hline \multirow{3}{*}{$\begin{array}{l}\text { General } \\
\text { users }\end{array}$} & $\begin{array}{l}\text { Trustworthiness } \\
\text { + Relative } \\
\text { advantages }\end{array}$ & $\begin{array}{l}\text {-Yes, truly I can rely on information provided by Google Home (GU11). } \\
\text {-I can trust CAs. Because I need it. I mean you are putting a machine just } \\
\text { like your friends, sometimes you don't have friend (GU18). } \\
\text {-When I talk to Siri, it interacts with me in natural way. So, I have the } \\
\text { feeling that I am interacting with a person that I cannot see (GU19). } \\
\text {-Yes, the voice has to be confident voice. Confident voice is very } \\
\text { important. If we are human, subconsciously we listen the people who are } \\
\text { confident. If the voice is not confident, I will not trust it (GU14). }\end{array}$ \\
\hline & $\begin{array}{l}\text { Relative } \\
\text { advantages }\end{array}$ & $\begin{array}{l}\text {-Using CAs enhances the quality and efficiency of my performance } \\
\text { (GU2). } \\
\text {-Using CAs helps me to get things done more quickly and efficiently } \\
\text { (GU4). } \\
\text {-Using CAs are one kind of relative advantage (GU11). } \\
\text {-Of course, the work performance will be better using CAs (GU16). }\end{array}$ \\
\hline & Not use any CAs & $\begin{array}{l}\text {-I do not use any of the CAs. I actually prefer not to use any of them. } \\
\text { Because it will make me lazy (GU2). }\end{array}$ \\
\hline \multirow[t]{2}{*}{ Expert users } & $\begin{array}{l}\text { Relative } \\
\text { advantages }\end{array}$ & $\begin{array}{l}\text {-For me functionality is important. I trust on CAs based on its capability } \\
\text { of doing tasks (EU5). } \\
\text {-I do not care about fashion but I care about total function. To me it is } \\
\text { functionality. I really go for the convenience and the functionality whether } \\
\text { I really need or not (EU8). } \\
\text {-Eventually, I could imagine that CAs will make you more self-reliant. As } \\
\text { you will get all of insights or recommendations. Using those insights, you } \\
\text { feel more in controlled over your tasks (EU9). }\end{array}$ \\
\hline & Not use any CAs & $\begin{array}{l}\text {-I want to have a direct contact with nature. Just person to nature } \\
\text { without the intermediary devices. I want to be in direct contact with } \\
\text { the physical world and other people. I prefer eye-to-eye contact. I do } \\
\text { not want to see somebody on the screen. I want to see people eye- } \\
\text { to-eye, and face-to-face. So that I want to feel the emotions in the } \\
\text { friendships directly (EU2). }\end{array}$ \\
\hline
\end{tabular}

The results of this study show that there are early adopters and early majority in the service system. As early adopters, expert users' attitude toward CAs is relative advantage. They use CAs based on advantages they receive while using CAs. They consider CAs as low level. Trustworthiness is the attitude of general users as early majority. They use CAs based on the trustworthiness towards CAs. They consider CAs as high level. The first and second circles in the figure 1 are based on the results of this research. 


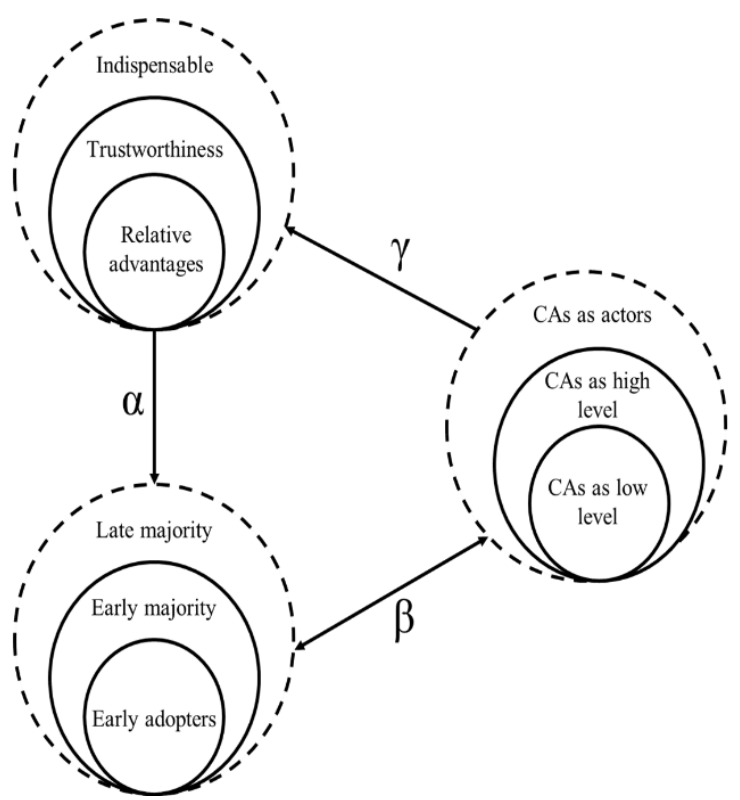

Figure 1. A service system in which CAs will evolve as actors

By considering the results of this study, we predict that late majority will evolve and they will consider CAs as actors in service system, and at that time CAs will be ubiquitous as well as indispensable part in the society. The outermost dashed circles in figure 1 show our prediction. The results of this research indicate that the future technological capabilities will improve over the period of time through the users' interactions with CAs. In addition, the findings of this research suggest that the evolution of technology will never stop. For example, we believe the results from calculator. We never doubt about the results from calculator. But in the early age, we doubt the results from calculator. At that time, people rechecked the results from calculator. So, the technology will evolve and people's attitude towards technology will also change. Furthermore, the results of this research suggest that technology development evolution is inevitable. As a result, current CAs will evolve as actors in service system through the people's partnership with CAs.

Why outermost dashed circles will evolve soon? Because the diffusion theory [35] suggests that an innovation evolves not at once but step by step. The results of this study show that CAs as innovation first accepted by early adopters, then early majority, and finally late majority. Late majority will start to use CAs (technologies) in the condition that CAs (technologies) become very ubiquitous and will be no choices or alternatives for them. At that time, late majority will consider CAs as actors in service system and CAs will be regarded as indispensable part of the society. And the reason for late majority to use CAs will be different. For late majority, there will be no choices or alternatives. Almost everyone in the society will use CAs and consider CAs as actors in the service system.

Table 5. Meaning of transitions and their relationships

\begin{tabular}{|c|l|}
\hline Arrows & \multicolumn{1}{|c|}{ Meaning } \\
\hline$\alpha$ & $\begin{array}{l}\alpha \text { is the transition in diffusion. It helps to } \\
\text { diffuse CAs among the people in the } \\
\text { service system. }\end{array}$ \\
\hline$\beta$ & $\begin{array}{l}\beta \text { is the transition in interactions between } \\
\text { people and CAs. It helps CAs to offer new } \\
\text { services (value proposition) through the } \\
\text { continuous interactions with people. At } \\
\text { the same time, it also helps people to } \\
\text { determine new types of benefits through } \\
\text { the interactions with CAs. }\end{array}$ \\
\hline$\gamma$ & $\begin{array}{l}\gamma \text { is the transition in influencers. It helps to } \\
\text { emerge new types of influencers through } \\
\text { the continuous interactions between CAs } \\
\text { and users. }\end{array}$ \\
\hline
\end{tabular}

\subsection{Transition in diffusion}

The transition in diffusion indicates the adoption of CAs by the people in the service systems due to perceived advantages provided by the CAs and trustworthiness of the CAs. It helps to diffuse CAs by the people in the service system in different phases by expanding the inner circle to outer circle. The results of this research show that initially CAs are adopted by the expert users as early adopters. Then expert users as early adopters changed to general users as early majority. Through these ways, late majority will evolve as a result of transition in diffusion of CAs among the people in the society. In this case expert users expressed that:

I think as a developer of CAs, currently I am using it based on the functionalities. After few years, I will change my role. That's means I will start to use CAs without considering the functionalities. Because CAs will gain my belief through continuous interactions with me. Again, new kinds of people will start to use CAs in the near future when CAs will be very common to every people in our society (EU5).

I have been developing and using technologies for all of my life. I am using personal computer from 1984. I started using cell phone from 1994. I started using smartphone from 2004 till now. So, I see every after 10 years, mass people start to use technologies. So, if I think as an experienced user, the capabilities of CAs are 
limited; as a general user of CAs, in the near future mass people will start to use CAs (EU1).

\subsection{Transition in interactions}

The transition in interactions indicate the partnership between people and CAs will help to evolve CAs as actors in the service system. As the results of this research indicate that the evolution of CAs (AI) is inevitable through the people's partnership with CAs. The results also show that expert users consider CAs as low level and general users consider CAs as high level. Therefore, this transition will help CAs to improve its capabilities and will evolve as actors by playing new roles in the service system. In this case, expert users indicated in the following ways:

Absolutely, CAs will get more capabilities in the coming years. They are already learning from the users' interactions with them(EU5).

I believe as AI, the functionalities of CAs will continue to advance. I will see more and more capabilities of CAs. I think it is very positive that they are learning about me and evolving through the partnership with me (EU8).

I think the context understanding capabilities of CAs will improve a lot. I also believe new type of CAs will evolve through the partnership with us. And definitely, that time we will have real partnership with CAs (EU9).

\subsection{Transition in influencers}

The transition in influencers indicates the evolution of new types of influencers in the service system through the continuous interactions between CAs and people. The results of this research show that relative advantages and trustworthiness are the attitudes of expert (early adopters) and general (early majority) users toward CAs. Therefore, the transition in influencers indicates that in the future CAs will be indispensable part of the society. At that time, mass people (late majority) will start to use CAs and there will be no alternatives at that time. The expert users expressed in the following ways:

I think in the near future, CAs will become part of our society. I will allow them to make more decision. That mean I will allow them to make decision for me but I would like to be informed (GU8).

I think CAs are changing our behavior toward them. So, I believe I will adapt my behavior according to the changes in the capabilities of CAs (EU4).
I think new collaboration will happen. So new attitude will evolve. That time there will be no alternatives. We must have to use CAs (EU9).

\section{Conclusion and Future Research Directions}

Theoretically, this is the first research designed and developed a service system in which CAs evolve as actors in the service systems. This research broadens the fields of service science and S-D logic. In a nutshell, CAs are evolving and will evolve as indispensable part of service systems. As a result, people will consider CAs as actors and at that time, people will not have any choices or alternatives. However, there are several practical implications of this research for contributing in service science, service-dominant (S-D) logic, knowledge science, design science, human interaction with agents, human-computer interaction and technology companies all over the world.

First and foremost, this research broadens the area of service science and S-D logic. The proposed service system in which CAs evolve as actors-provide a new way of re-thinking about the role of emerging technologies (AI) in service systems. It broadens the areas of service science and S-D logic by introducing and explaining three types of transitions namely transition in diffusion, transition in interactions and transition in influencers. Ultimately, these transitions lay down the foundation to evolve CAs as actors in service systems. More broadly, over the period of time, CAs will gain rights and they will behave responsibly with people in service system.

Secondly, innovation is diffused over time among the participants in a social system. Therefore, early adopters and early majority will evolve as late majority in service systems. As the inevitable future is CAs will understand more people's emotions, feelings, environment and context. Therefore, CAs eventually will evolve as actors in service systems. At that time mass people in society will accept CAs. As CAs will be indispensable part of service systems. Last but not least, this research identifies that trustworthiness and relative advantages towards using CAs. Therefore, the designers and developers of CAs will be benefited from this research. So, in the future, designers, and developers as well technology companies could develop more trusted CAs with high level functionalities.

This research is not free from limitations. There are several limitations of this research. First, the expert interviews were conducted at only one technology company in the USA. Therefore, future research should be carried out covering several companies in which they have their own CAs. Second, this research proposed a service system in which CAs evolve as actors. To evolve 
as actors, this research introduces three types of transitions in service systems. Ultimately these transitions lay down the foundation to evolve CAs as actors in service systems. Therefore, future research should conduct to more deeply understand the relationships among the transitions and how could these transitions be connected to the institutions in S-D logic.

\section{Acknowledgement}

This research is supported by the Grants-in-Aid for JSPS Fellows (Project Number 19F19308).

\section{References}

[1] Akaka, M. A. and Vargo, S. L. (2014). Technology as an operant resource in service (eco)systems. Information Systems and e-Business Management, 12(2), pp. 357-384.

[2] Arthur, W. B. (2009). The nature of technology: What it is and how it evolves. New York: Simon and Schuster.

[3] Bandura, A. (1999). Social cognitive theory: an agentic perspective. Asian Journal of Social Psychology, 2, 21-41.

[4] Bostrom, N. (2014). Superintelligence: Paths, dangers, strategies. Oxford, UK: Oxford University Press.

[5] Bourdieu, P. (1977). Outline of a theory of practice. Cambridge: Cambridge University Press.

[6] Coole, D. (2010). Agency. Encyclopedia Britannica. Available at: https://www.britannica.com/topic/agencypolitical-theory.

[7] Corbin, J. and Strauss, A. (2015). Basics of qualitative research: techniques and procedures for developing grounded theory. $4^{\text {th }}$ edition. Los Angeles: Sage.

[8] Davis, F.D. (1989). Perceived usefulness, perceived ease of use and user acceptance of information Technology. MIS Quarterly, 13(3), 319-340.

[9] Eisenhardth, K. M. and Graebner, M. E. (2007). Theory building from cases: opportunities and challenges. Academy of Management Journal, 50, pp. 25-32.

[10] EU (2018). A new era for data protection in the EU: what changes after May 2018. Available at: https://ec.europa.eu/commission/sites/betapolitical/files/data-protection-factsheet-changes_en.pdf.

[11] Gephart, J. H. (2004). Qualitative research and the Academy of Management Journal. Academy of Management Journal, 47, pp. 554-562.

[12] Giddens, A. (1984). The construction of society: outline of the theory of structuration. Berkeley and Los Angeles: University of California Press.

[13] Glaser, B and Strauss, A. (1967). The discovery of grounded theory. Hawthorne, NY: Aldine Publishing Company.

[14] Ito, J. (2018). AI isn't a crystal ball, but it might be a mirror. MIT Media Lab. Available at: https://www.wired.com/story/ideas-ai-as-mirror-notcrystal-ball/

[15] Jian, J. Y., Bisantz, A. M., \& Drury, C. G. (2000). Foundations for an empirical determined scale of trust in automated systems. International Journal of Cognitive Ergonomics, 4(1), 53-71.
[16] Kaartemo, V., Jaakkola, E., and Alexander, M. (2019). Roles of technology in actor engagement. In the proceedings of $16^{\text {th }}$ International Research Symposium on Advancing Service Research and Practice, $10-13^{\text {th }}$ of June, Karlstad, Sweden.

[17] Latour, B. (2005). Reassembling the social: an introduction to actor-network theory. Oxford, UK: Oxford University Press.

[18] Lusch, R. F. and Vargo, S. L. (2014). Service-dominant logic: premises, perspectives, possibilities. Cambridge: Cambridge University Press.

[19] Maglio, P. P. (2014). Editorial column-smart service systems. Service Science, 6(1), pp. i-ii.

[20] Maglio, P. P. (2017). Editorial column - new directions in service science: value cocreation in the age of autonomous service systems. Service Science, 9(1), pp. 1-2.

[21] Maglio, P. P. and Spohrer, J. (2008). Fundamentals of service science. Journal of the academy of marketing science, 36(1):18-20.

[22] Maglio, P. P. and Spohrer, J. (2013). A service science perspective on business model innovation. Industrial Marketing Management, 42, pp. 665-670.

[23] Maglio, P. P., Vargo, S. L., Caswell, N., and Spohrer, J. (2009). The service system is the basic abstraction of service science. Information Science and e-Business Management, pp. 395-406.

[24] Mayer, R. C., Davis, J. H., \& Schoorman, F. D. (1995). An integrative model of organizational trust. Academy of Management Review, 20(3), 709-734.

[25] Merriam-Webster (2018). Agency. https://www.merriamwebster.com/dictionary/agency (Retrieved on April 18, 2018).

[26] Nwana, H. S. (1996). Software agents: an overview. Knowledge Engineering Review, 21(3), pp. 205-244.

[27] Orlikowski, W. (1992). The duality of technology: rethinking of the concept of technology in organizations. Organization Science, 3(3), pp. 398-427.

[28] Ostrom, A. L., Foheringham, D., Bitner, M. J. (2018). Customer acceptance of AI in service encounters: understanding antecedents and consequences. In Handbook of Service Science, Volume 2, Eds, Maglio, Kieliszewski, Spohrer, Lyons, Patricio, Sawatani. New York: Springer.

[29] Ostrom, E. (2005). Understanding institutional diversity. Princeton: Princeton University Press.

[30] Oxford Living Dictionaries (2018). Agency. Available at: https://en.oxforddictionaries.com/definition/agency.

[31] Pakkala, D. and Spohrer, J. C. (2019). Digital service: technological agency in service systems. Proceedings of the 52nd HICSS conference. USA Hawaii Maui.

[32] Parasuraman, A. (2000). Technology readiness index (TRI): a multiple-item scale to measure readiness to embrace new technologies. Journal of Service Research, 2(4), pp. 307-320.

[33] Rempel, J. K., Holmes, J. G., \& Zanna, M. P. (1985). Trust in close relationships. Journal of Personality and Social Psychology, 49(1), 95-112.

[34] Rao, A. S., \& Verweij, G. (2017). Sizing the prize, what's the real value of AI for your business and how can you capitalize? PwC Publication. Retrieved from https://www.pwc.com/gx/en/issues/analytics/assets/pwcai-analysis-sizing-the-prize-report.pdf. 
[35] Rogers, E. M. (2003). Diffusion of innovations. New York: Free Press.

[36] Ross, S. A. (1973). The economic theory of agency: the principal's problem. The American Economic Review, 63(2), pp. 134-139.

[37] Schlosser, M. (2015). Agency. The Stanford Encyclopedia of Philosophy (Fall 2015 Edition), Edward N. Zalta (ed.). Available at: $<$ https://plato.stanford.edu/archives/fall2015/entries/agenc $\mathrm{y} />$.

[38] Siddike, M. A. K. \& Kohda, Y. (2018a). Co-creating value in people's interactions with cognitive assistants: a service system view. Journal of Creating Value, 4(2), 255272.

[39] Siddike, M. A. K. \& Kohda, Y. (2018b). Towards a framework of trust determinants in people and cognitive assistants interactions. In proceedings of the 51th Hawaii International Conference on System Sciences (HICSS 51). Hawaii: University of Hawaii.

[40] Siddike, M. A. K. \& Kohda, Y. (2018c). Use of metaphors for acceptance of cognitive assistants: a qualitative study. International Journal of Society of Systems Science, 10(4), 243-258.

[41] Siddike, M. A. K. \& Kohda, Y. (2019). Trust in cognitive assistants: a theoretical framework. International Journal of Applied Industrial Engineering, 6(1), 60-71.

[42] Siddike, M. A. K., Iwano, K., Hidaka, K., Kohda, Y., \& Spohrer, J. (2017). Wisdom service systems: harmonious interactions with people and machines. In L. E. Freund and W. Cellary (eds.), Advances in The Human Side of Service Engineering, Advances in Intelligent Systems and Computing 601. Cham: Springer.

[43] Siddike, M. A. K., Spohrer, J., Demirkan, H., \& Kohda, Y. (2018a). People's interactions with cognitive assistants for enhanced performances. In proceedings of the 51st Hawaii International Conference on System Sciences (HICSS 51). Hawaii: University of Hawaii.

[44] Siddike, M. A. K., Spohrer, J., Demirkan, H., \& Kohda, Y. (2018b). People's interactions with cognitive assistants for enhanced performances. International Journal of Systems and Service-Oriented Engineering, 8(3), 1-17.

[45] Spohrer, J. \& Banavar, G. (2015). Cognition as a service: an industry perspective. AI Magazine, 36(4), 71-86.

[46] Spohrer, J. (2016). Innovation for jobs with cognitive assistants: a service science perspective. In D. Nordfors, V. Cerf, \& M. Senges (eds.), Disrupting Unemployment. Missouri, USA: Ewing Marion Kauffman Foundation.

[47] Spohrer, J. and Banavar, G. (2015). Cognition as a service: an industry perspective. AI Magazine, 36(4), 2015, pp. 71-86.

[48] Spohrer, J. and Maglio, P. P. (2008). Fundamentals of service science. Journal of the Academy of Marketing Science, 26(1), 18-20.
[49] Spohrer, J. and Maglio, P. P. (2009) Service science: toward a smarter planet. In Service Engineering, ed. Karwowski \& Salvendy. Wiley. New York, NY.

[50] Spohrer, J. Siddike, M. A. K., \& Kohda, M. A. K. (2017). Rebuilding evolution: a service science perspective. In proceedings of the 50th Hawaii International Conference on System Sciences (HICSS 50). Hawaii: University of Hawaii.

[51] Spohrer, J., Bassano, C., Piciocchi, P., \& Siddike, M. A. K. (2017). What makes a system smart? wise? Advances in The Human Side of Service Engineering, 27-31.

[52] Spohrer, J., Kwan, S. K. and Fisk, R. P. (2014). Marketing: a service science and arts perspective. In Handbook of service marketing research (eds. R. T. Rust and M. Huang), UK: Edward Elgar, pp. 489-526.

[53] Spohrer, J., Maglio, P. P., Bailey, J. and Gruhl, D. (2007). Steps toward a science of service systems. IEEE Computer, (40)1:71-77.

[54] Spohrer, J., Vargo, S. L., Casewell, N., and Maglio, P. P. (2008). The service system is the basic abstraction of service science. In the Proceedings of $41^{\text {st }}$ Hawaii International Conference on System Sciences, New York, USA: IEEE Press, pp. 1-10.

[55] Symon, G. and Cassell, C. (2012). Qualitative organizational research: core methods and current challenges. Los Angeles: Sage.

[56] Vargo, S. L. and Akaka, M. A. (2012). Value co-creation and service systems (re)formation: a service ecosystems view. Service Science, 4(3), pp. 207-217.

[57] Vargo, S. L. and Lusch, R. F. (2004). Evolving to a new dominant logic for marketing. Journal of Marketing, 68(January), pp. 1-17.

[58] Vargo, S. L. and Lusch, R. F. (2008). Service-dominant logic: continuing the evolution. Journal of the Academy of Marketing Science, 36, 1-10.

[59] Vargo, S. L. and Lusch, R. F. (2016). Institutions and axioms: an extension and update of service-dominant logic. Journal of the Academy of Marketing Science, 44(1), 5-23.

[60] Vargo, S. L. and Lusch, R. F. (2017). Service-dominant logic 2025. International Journal of Research in Marketing, 34(1), pp. 46-67.

[61] Weaver, J. F. (2017). What exactly does it mean to give a robot citizenship? It's complicated. Slate.com. http://www.slate.com/articles/technology/future_tense/201 7/11/what_rights_does_a_robot_get_with_citizenship.html

[62] Williamson, O. E. (1985). The economic institutions of capitalism: firms, markets, relational contracting. New York: The Free Press.

[63] Williamson, O. E. (1996). The mechanisms of governance. Oxford: Oxford University Press.

[64] Willig, C. (2001). Introducing qualitative research in psychology: adventures in theory and method. Buckingham: Open University Press. 